\title{
PENGARUH NPL, BIAYA OPERASIONAL PENDAPATAN OPERASIONAL, LOAN TO DEPOSIT RATIO, DAN CAR TERHADAP ROA
}

\author{
Kade Devi Anggreningsih ${ }^{1}$ \\ Made Surya Negara ${ }^{2}$ \\ ${ }^{1,2}$ Fakultas Ekonomi dan Bisnis Universitas Udayana, \\ Bali, Indonesia \\ email : devianggreni40@gmail.com
}

\begin{abstract}
ABSTRAK
Tujuan penelitian ini adalah untuk menguji dan menganalisis variable-variabel penentu profitabilitas pada industri perbankan di Bursa Efek Indnesia. Variabel-variabel penentu profitabilitas suatu bank yang diukur dengan Return on Asset (ROA) tersebut antara lain: Non Performing Loan (NPL), Biaya Operasional Pendapatan Operasional (BOPO), Loan to Deposit Ratio (LDR), dan Capital Adequacy Ratio (CAR). Metode penentuan sampel dalam penelitan ini adalah purposive sampling. Teknik analisis data dalam penelitian ini adalah analisis regresi linier berganda. Hasil penelitian menunjukkan bahwa NPL dan BOPO berpengaruh negatif terhadap ROA, sedangkan LDR dan CAR berpengaruh positif terhadap ROA. Implikasi teoritis dari penelitian ini adalah untuk meningkatkan profitabilitas suatu bank, maka manajemen bank tersebut harus dapat menekan NPL dan BOPO, serta meningkatkan LDR dan CAR. Implikasi praktis dari penelitian ini adalah manajemen bank harus selalu mengedepankan prinsip kehati-hatian dalam penyaluran kredit, serta selalu meningkatkan efisiensi dalam operasional sehingga peningkatan profitabilitas dapat tercapai. Manajemen juga harus dapat memelihara tingkat penyaluran kredit yang optimal dan memenuhi kecukupan modal sehingga dapat meningkatkan profitabilitas.
\end{abstract}

Kata kunci : NPL, BOPO, LDR, CAR, dan ROA

\begin{abstract}
The purpose of this study was to test and analyze the determinants of profitability in the banking industry on the Indonesian Stock Exchange. The variables that determine the profitability of a bank as measured by Return on Assets (ROA) include: Non Performing Loans (NPL), Operating Costs for Operating Income (BOPO), Loan to Deposit Ratio (LDR), and Capital Adequacy Ratio (CAR). . The method of determining the sample in this research is purposive sampling. The data analysis technique in this study is multiple linear regression analysis. The results showed that NPL and BOPO had a negative effect on ROA, while LDR and CAR had a positive effect on ROA. The theoretical implication of this research is to increase the profitability of a bank, the bank management must be able to suppress NPL and OEOI, as well as increase LDR and CAR. The practical implication of this research is that bank management must always prioritize the principle of prudence in lending, and always increase efficiency in operations so that increased profitability can be achieved. Management must also be able to maintain an optimal level of lending and meet capital adequacy so as to increase profitability.
\end{abstract}

Keywords: NPL, OEOI, LDR, CAR, and ROA 


\section{PENDAHULUAN}

Bank adalah lembaga keuangan yang berfungsi menghimpun dana dari masyarakat dan menyalurkan dana kepada masyarakat. Bank berfungsi sebagai tempat untuk meminjam dana bagi masyarakat yang membutuhkannya dan tempat menghimpun dana dari masyarakat yang memiliki kelebihan dana (Kasmir, 2016:24). Kinerja suatu bank sangat perlu diperhatikan karena kinerja suatu bank menentukan tingkat kepercayaan masyarakat terhadap bank tersebut (Kasmir, 2017:4). Makin baik kinerja suatu bank, makin besar kepercayaan masyarakat kepada bank tersebut. Dari persepektif keuangan terdapat beberapa indikator utama untuk menilai kinerja suatu bank. Indikator utama tersebut antara lain yaitu perbandingan kredit bermasalah dengan total kredit atau non performing loan (NPL), perbandingan antara biaya operasional dan pendapatan operasional atau biaya operasional pendapat operasional (BOPO), perbandingan antara total kredit dan total dana pihak ketiga (DPK) atau loan to deposit ratio (LDR), perbandingan antara jumlah modal dalam bank dengan modal berdasarkan ATMR atau capital adequacy ratio (CAR), dan perbandingan antara laba bank sebelum pajak dengan rata-rata total aset bank atau return on asset (ROA).

Profitabilitas bank adalah tolok ukur yang digunakan bank untuk menilai kinerja seberapa efektif dan efisien suatu bank beroperasi guna mengahasilkan keuntungan dari aset yang dimiliki. Profitabilitas menjelaskan kemampuan perusahaan untuk mendapat untung melalui semua kemampuan dari sumber yang ada (Buchory, 2015). Tingginya profitabilitas suatu bank dapat menunjukkan bahwa sebagian besar kinerja bank tersebut beroperasi secara efektif dan efisien (Warsa \& Mustanda, 2016). Profitabilitas dapat dinilai dengan menggunakan rasio profitabilitas ROA. Menurut Riyadi (2006:156) ROA adalah rasio profitabilitas yang menunjukan perbandingan antara laba (sebelum pajak) dengan total asset. ROA lebih berfokus menghitung kemampuan efektifitas perusahaan perbankan dalam mengelola aktiva yang dimilikinya untuk menghasilkan keuntungan.

Tahun 2014-2016, ROA sektor perbankan di Indonesia mengalami penurunan cukup drastis dari 2,85 persen menjadi 2,23 persen. Tahun 2016-2018, ROA sektor perbankan di Indonesia mengalami peningkatan sebesar 2,42 persen. Perubahan besarnya ROA pada sektor perbankan di Indonesia mendorong dilakukan penelitian tentang risiko bank seperti NPL, BOPO, LDR, dan CAR yang memengaruhi perubahan ROA pada sektor perbankan di Indonesia.

NPL merupakan rasio yang digunakan untuk menilai risiko kredit pada bank. Risiko kredit merupakan salah satu risiko yang signifikan dihadapi bank. Keberhasilan pengelolaan risiko kredit tergantung pada pengukuran yang akurat rasio NPL dan manajemen yang efektif dan efisien dalam mengelola risiko kredit tersebut. Kerugian dari risiko kredit terjadi jika peminjam bank gagal membayar berdasarkan perjanjian dan segala kegagalan tersebut dapat berdampak negatif pada kinerja keuangan bank (Bhattarai, 2016). Kredit merupakan salah satu pendapatan terbesar pada bank. Jika pembayaran kredit gagal, maka kemampuan bank untuk memberikan pinjaman baru akan terbatas (Buchory, 2015). Kredit yang gagal akan menyebabkan pembentukan Penyisihan Penghapusan Aktiva Produktif (PPAP) atau cadangan kerugian akan meningkat yang menyebabkan pendapatan dari bunga pinjaman akan berkurang dan bank harus membentuk 
cadangan kerugian pinjaman yang akhirnya akan mengurangi profitabilitas serta dapat mempengaruhi biaya opersional pendapatan operasional.

BOPO adalah rasio yang digunakan untuk menilai biaya yang digunakan bank serta pendapatan yang diperoleh bank untuk menilai seberapa efisien dan efektif operasional bank tersebut. Biaya operasi adalah biaya yang dikeluarkan oleh bank untuk melakukan kegiatan bisnis utama (Utami, 2015). Pendapatan operasional adalah pendapatan utama bank, sedangkan pendapatan bunga diperoleh dari penempatan dana dalam bentuk kredit dan pendapatan operasional lainnya (Utami, 2015). BOPO merupakan rasio yang digunakan untuk menilai risiko operasional bank. Selain harus memperhatikan risiko operasional, perbankan juga harus memperhatikan risiko likuiditas melalui rasio LDR.

Menurut Kasmir (2017:319) LDR adalah rasio yang digunakan untuk mengukur komposisi jumlah kredit yang diberikan oleh dana pihak ketiga dan modal sendiri yang digunakan bank. Suatu perbankan dapat dikatakan baik apabila perbankan dapat mengatasi risiko likuiditasnya. Risiko likuiditas mencerminkan kemampuan bank untuk mendistribusikan dana pihak ketiga (DPK) untuk kredit, jika tidak demikian akan ada uang menganggur yang akan menyebabkan naiknya biaya peluang dan perubahan profitabilitas menjadi rendah (Utami, 2015). Menurut Wiagustini (2014:88) Risiko likuiditas adalah risiko perusahaan untuk memenuhi kewajiban jangka pendek pada saat jatuh tempo. Likuiditas pada perbankan dipengaruhi oleh salah satu risiko bank yaitu risiko modal melalui CAR dalam pengoptimalan profitabilitas bank tersebut.

Menurut Riyadi (2006:161) "capital adequacy ratio adalah rasio kewajiban pemenuhan modal minimum yang harus dimiliki oleh bank". Menurut Peraturan Bank Indonesia No.15/12/PBI/2013 menyebutkan penyediaan modal minimum sebesar 8\% (delapan persen) dari aset tertimbang menurut risiko (ATMR) untuk bank dengan profil risiko peringkat 1 (satu). Rasio CAR yang baik dapat membantu dalam memanajemen efektif dan efisien risiko modal pada suatu bank. Menurut Kasmir (2017:325) "Risiko modal dapat terjadi karena kegagalan mengukur permodalan dan cadangan penghapusan (PPAP) dalam menanggung perkreditan". Kegagalan dalam pengelolaan modal yang sering terjadi tentunya dapat menurunkan profitabilitas dalam bank.

Penelitian NPL berpengaruh terhadap ROA telah dilakukan oleh beberapa Peneliti. Hasil penelitian Puspitasari et al., (2015), Petria et al., (2015), Prasetyo \& Darmayanti (2015), Bhattarai (2016), Chimkono et al., (2016), Warsa \& Mustanda (2016), Ariwidanta (2016), Silaban (2017), Yudha et al., (2017), Kadioglu et al., (2017), Putri \& Dewi (2017), Hakim \& Sugianto (2018), Peling \& Sedana (2018), Putri dkk. (2018), Afriyeni \& Fernos (2018), serta Paramita \& Dana (2019) menyatakan bahwa NPL berpengaruh negatif dan signifikan terhadap ROA. Hal ini disimpulkan bahwa peningkatan NPL akan menyebabkan penurunan ROA. Disisi lain, hasil penelitian Febriyono (2015), Vernanda \& Widyarti (2016), Kusmayadi (2018), Purnomo dkk. (2018) serta Akbar dkk. (2018) menyatakan "NPL berpengaruh negatif dan tidak signifikan terhadap ROA". Hasil penelitian Buchory (2015), Iftikhar (2016), serta Anwar \& Murwaningsari (2017) menyatakan bahwa NPL berpengaruh positif dan 
signifikan terhadap ROA. Disisi lain, hasil penelitian Buchory (2015) menyatakan bahwa NPL berpengaruh positif dan tidak signifikan terhadap ROA.

Penelitian BOPO berpengaruh terhadap ROA. Hasil penelitian Buchory (2015), Utami (2015), Buchory (2015), Prasetyo \& Darmayanti (2015), Vernanda \& Widyarti (2016), Yusuf \& Surjaatmadja (2018), Juwita et al. (2018), Kusmayadi (2018), Peling \& Sedana (2018), Purnomo dkk. (2018), Putri dkk. (2018), Afriyeni \& Fernos (2018) serta Yuniari \& Badjra (2019) menyatakan bahwa BOPO berpengaruh negatif dan signifikan terhadap ROA. Hal ini disimpulkan bahwa peningkatan BOPO akan menyebabkan penuruan ROA. Disisi lain, hasil penelitian Chou \& Buchdadi (2016) menyatakan bahwa BOPO berpengaruh negatif dan tidak signifikan terhadap ROA. Hasil sebaliknya didapatkan bahwa BOPO berpengaruh positif terhadap ROA. Hasil penelitian Akbar dkk. (2018) menyatakan bahwa BOPO berpengaruh positif dan signifikan terhadap ROA. Disisi lain, hasil penelitian Hakim \& Sugianto (2018) menyatakan bahwa BOPO berpengaruh positif dan tidak signifikan terhadap ROA .

Penelitian LDR berpengaruh terhadap ROA. Hasil penelitian Utami (2015), Prasetyo \& Darmayanti (2015), Chou \& Buchdadi (2016), Yudha et al. (2017), Putri \& Dewi (2017), Juwita et al. (2018), Peling \& Sedana (2018), Afriyeni \& Fernos (2018), Paramita \& Dana (2019) serta Yuniari \& Badjra (2019) menyatakan bahwa LDR berpengaruh positif dan signifikan terhadap ROA. Hal ini disimpulkan bahwa penurunan LDR dapat menyebabkan penurunan ROA. Disisi lain, hasil penelitian Puspitasari et al. (2015), Febriyono (2015), Warsa \& Mustanda (2016), Vernanda \& Widyarti (2016) serta Kusmayadi (2018) menyatakan bahwa LDR berpengaruh positif dan tidak signifikan terhadap ROA. Hasil sebaliknya didapatkan bahwa LDR berpengaruh negatif terhadap ROA. Hasil penelitian Hakim \& Sugianto (2018) menyatakan bahwa LDR berpengaruh negatif dan signifikan terhadap ROA. Disisi lain, Hasil Penelitian Buchory (2015), Petria et al. (2015), serta Purnomo dkk. (2018) menyatakan bahwa LDR berpengaruh negatif dan tidak signifikan terhadap ROA

Penelitian CAR berpengaruh terhadap ROA. Hasil penelitian Utami (2015), Iftikhar (2016), Vernanda \& Widyarti (2016), Putri \& Dewi (2017), Juwita et al. (2018), Yusuf \& Surjaatmadja (2018), Akbar dkk. (2018), Putri dkk. (2018), Afriyeni \& Fernos (2018), Atmoko, dkk. (2018) serta Paramita \& Dana (2019) menyatakan bahwa CAR berpengaruh positif dan signifikan terhadap ROA. Hal ini disimpulkan bahwa penurunan CAR dapat menyebabkan penurunan ROA. Disisi lain, hasil penelitian Puspitasari et al. (2015), Petria et al. (2015), Chou \& Buchdadi (2016), Warsa \& Mustanda (2016), Silaban (2017), serta Munawar (2017) menyatakan bahwa CAR berpengaruh positif dan tidak signifikan terhadap ROA.

Hasil sebaliknya didapatkan bahwa CAR berpengaruh negatif terhadap ROA. Hasil penelitian Ariwidanta (2016), Anwar \& Murwaningsari (2017), serta Hakim \& Sugianto (2018) menyatakan bahwa "CAR berpengaruh negatif dan signifikan terhadap ROA". Disisi lain, Hasil penelitian Prasetyo \& Darmayanti (2015), Bhattarai (2016), Kusmayadi (2018) serta Purnomo dkk. (2018) menyatakan bahwa CAR berpengaruh negatif dan tidak signifikan terhadap ROA. 
Berdasarkan penelitian sebelumnya menunjukan masih ada research gap pengaruh CAR terhadap ROA.

Berdasarkan uraian diatas, maka dapat diuraikan tujuan penelitian adalah untuk menguji dan menganalisis pengaruh NPL terhadap ROA pada perbankan di Indonesia, menguji dan menganalisis pengaruh BOPO terhadap ROA pada perbankan di Indonesia, menguji dan menganalisis pengaruh LDR terhadap ROA pada perbankan di Indonesia dan menguji dan menganalisis pengaruh CAR terhadap ROA)pada perbankan di Indonesia.

Penelitian ini terdiri dari variabel bebas adalah NPL, BOPO, LDR dan CAR dengan variabel terikat adalah ROA. Berdasarkan kajian teori dan hasil penelitian sebelumnya maka dapat dipaparkan hipotesis dalam kerangka konseptual sebagai berikut :

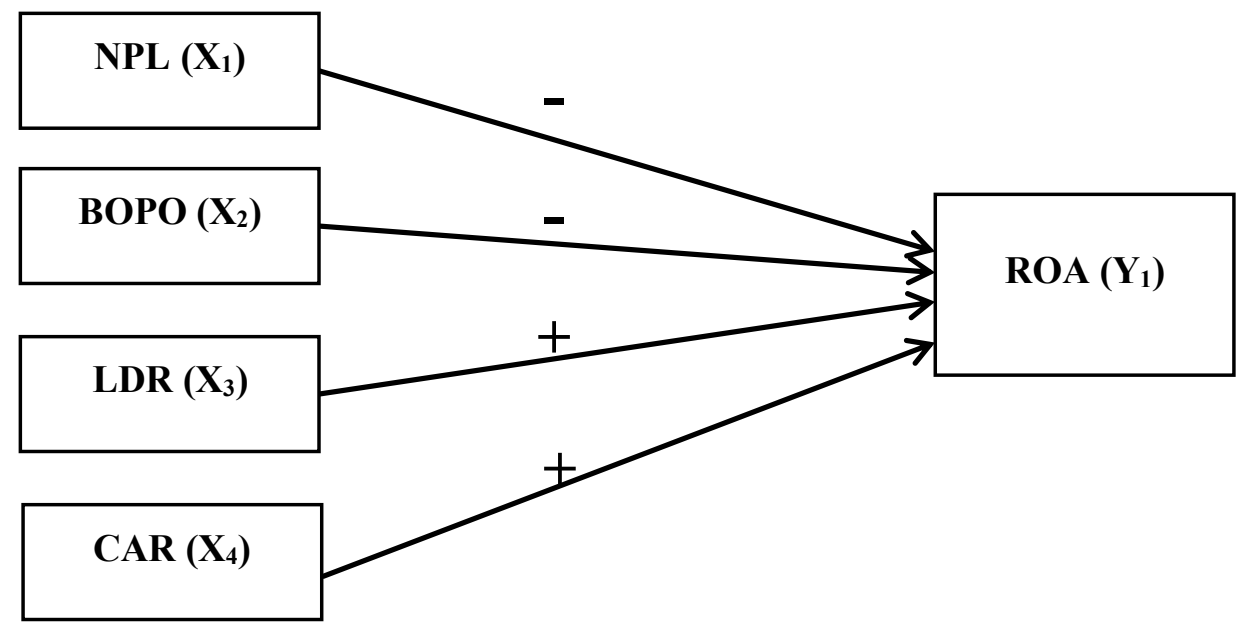

\section{Gambar 1. Kerangka Konseptual Penelitian}

Kredit merupakan pinjaman yang diberikan bank kepada nasabahnya. Kredit dalam bank akan selalu mempunyai risiko kredit bermasalah. Risiko kredit bermasalah merupakan salah satu faktor yang dapat mengurangi ROA pada bank. Risiko kredit sendiri dapat diukur menggunakan rasio NPL. Hasil penelitian mengenai NPL berpengaruh negatif terhadap ROA dilakukan oleh penelitian Puspitasari et al., (2015). Hasil penelitian Kadioglu et al., (2017) juga mengatakan adanya pengaruh negatif terhadap ROA yang dapat meningkatkan ROA dari penghindaran NPL yang bermasalah pada bank di Turki.

Hasil penilitian lainnya seperti penelitian Petria et al. (2015), Prasetyo \& Darmayanti (2015), Bhattarai (2016), Chimkono et al. (2016), Warsa \& Mustanda (2016), Ariwidanta (2016), Silaban (2017), Yudha et al. (2017), Hakim \& Sugianto (2018), Peling \& Sedana (2018), Afriyeni \& Fernos (2018), serta Paramita \& Dana (2019) selaras dengan hasil penelitian di atas menyatakan bahwa NPL berpengaruh negatif terhadap ROA.

$\mathrm{H}_{1}$ : NPL berpengaruh negatif terhadap ROA

BOPO adalah biaya yang digunakan bank serta pendapatan bank yang digunakan untuk menilai seberapa efektif dan efesien dari bank tersebut. Semakin kecil rasio BOPO maka semakin baik kinerja dari bank tersebut. Hasil Penilitan 
Utami (2015) mengatakan dengan analisis regresi yang digunakan menunjukan adanya pengaruh negatif terhadap ROA. Hal ini menunjukan semakin rendah pengaruh BOPO terhadap ROA dapat meningkatkan ROA karena hal tersebut memperlihatkan penekanan yang dilakukan di biaya operasional yang dikeluarkan bank dan peningkatkan pendapatan operasional bank yang dapat meningkatkan ROA tersebut pada bank milik negara dan bank asing di Indonesia. Hasil penelitian Juwita et al. (2018) juga mengatakan bahwa pengaruh rasio BOPO yang semakin rendah dapat meningkatkan rasio ROA pada bank tersebut.

Hasil penelitian lainnya seperti penelitian Buchory (2015), Prasetyo \& Darmayanti (2015), Vernanda \& Widyarti (2016), Yusuf \& Surjaatmadja (2018), Kusmayadi (2018), Peling \& Sedana (2018), Purnomo dkk. (2018), Putri dkk. (2018), Afriyeni \& Fernos (2018) serta Yuniari \& Badjra (2019) selaras dengan penelitian di atas yang menyatakan bahwa BOPO berpengaruh negatif terhadap ROA.

$\mathrm{H}_{2}$ : BOPO berpengaruh negatif terhadap ROA

Likuiditas bank digunakan untuk menilai seberapa mampu suatu bank memenuhi kewajiban jangka pendek pada saat jatuh tempo. Likuiditas bank dapat dihitung menggunakan rasio LDR. Hasil penelitian (Chou \& Buchdadi, 2016) menyatakan bahwa LDR berpengaruh positif terhadap ROA. Hasil penelitian Yudha et al., (2017) juga mengatakan bahwa semakin meningkat rasio LDR dapat meningkatkan profitabilitas bank yaitu rasio ROA tersebut pada bank di Indonesia periode 2010-2015. LDR yang positif atau meningkat dan signifikan terhadap ROA mengindifikasi bahwa ROA meningkat yang memperlihatkan kinerja suatu bank baik. Hal ini selaras dengan hasil penelitian Afriyeni \& Fernos (2018) dengan analisis linier berganda mengatakan bahwa LDR berpengaruh terhadap ROA.

Hasil penelitian lainnya seperti penelitian Utami (2015), Prasetyo \& Darmayanti (2015), Juwita et al. (2018), Peling \& Sedana (2018), Paramita \& Dana (2019) serta Yuniari \& Badjra (2019) juga selaras dengan hasil penelitian di atas yang menyatakan bahwa LDR berpengaruh positif terhadap ROA.

$\mathrm{H}_{3}$ : LDR berpengaruh positif terhadap ROA

Modal suatu bank berperan penting dalam mengatasi turunnya profitabilitas bank. CAR merupakan rasio yang digunakan untuk menilai seberapa baik pengolahan modal bank dalam menjaga profitabilitasnya (ROA). CAR yang mencukupi serta meningkat dapat menunjukkan peingkatan ROA pada bank tersebut. Hasil penelitian mengenai CAR terhadap ROA dilakukan oleh Penelitian Utami (2015). Hasil penelitian Iftikhar (2016) mengatakan bahwa rasio CAR yang memadai dalam suatu bank dapat menutupi kerugian bank serta meningkatkan rasio ROA pada bank di Pakistan. Hasil penelitian Vernanda \& Widyarti (2016) juga mengatakan bahwa CAR berpengaruh positif terhadap ROA. CAR yang positif menunjukkan peningkatan ROA pada suatu bank dalam meningkatkan kinerja bank tersebut.

Hasil penelitian lainnya seperti penelitian Juwita et al. (2018), Yusuf \& Surjaatmadja (2018), Akbar dkk. (2018), Putri dkk. (2018), Afriyeni \& Fernos (2018), Atmoko dkk. (2018) serta Paramita \& Dana (2019) selaras dengan 
penelitian di atas yang menyatakan bahwa CAR berpengaruh positif terhadap ROA.

$\mathrm{H}_{4}$ : CAR berpengaruh positif terhadap ROA

\section{METODE PENELITIAN}

Desain penelitian yang digunakan adalah penelitian asosiatif. Penelitian asosiatif adalah penelitian yang bertujuan untuk mengetahui pengaruh ataupun juga hubungan antara dua variabel atau lebih. Penelitian ini dilakukan untuk mengetahui hubungan antara variabel NPL, BOPO, LDR, dan CAR terhadap ROA. Lokasi penelitian dilakukan pada perbankan di Indonesia yang terdaftar di BEI. Alasan penelitian ini dilakukan pada perbankan di Indonesia, karena laporan keuangan bank yang sudah go public dan Indonesia mempunyai cakupan yang lebih besar sehingga diharapkan memberikan gambaran informasi yang lebih luas dan signifikan mengenai data yang akan diteliti. Adapun obyek penelitian ini adalah return on asset (ROA), non performing loan (NPL), biaya operasional pendapatan operasional (BOPO), loan to deposit ratio (LDR) dan capital adequacy ratio (CAR) pada bank umum negara dan swasta nasional di Indonesia yang terdaftar di Bursa Efek Indonesia (BEI). Dalam penelitian ini variabel bebas adalah NPL, BOPO, LDR dan CAR. Dalam penelitian ini variabel terikat adalah ROA.

Jenis data yang digunakan dalam peneletian ini adalah data kualitatif dan data kuantitatif. Data kualitatif penelitian ini adalah gambaran umum dari perbankan Indonesia dan data kuantitatif adalah data laporan keuangan bank umum negara dan swasta nasional per lima tahun yaitu periode 2014-2018 yang terdaftar di BEI. Sumber data penelitian ini adalah sumber data sekunder. Data sekunder yang diperoleh dari data laporan keuangan bank umum negara dan swata nasional per lima tahun yaitu periode 2014-2018 yang terdaftar di BEI yaitu www.idx.co.id. Penelitian ini menggunakan populasi bank umum negara dan swasta nasional di BEI yaitu 46 Perbankan. Sampel dalam penelitian ini menggunakan pendekatan purposive sampling.

Adapun pertimbangan tertentunya adalah 1) Laporan keuangan bank umum negara dan swasta nasional yang terdaftar di BEI dan masih beroperasi berturutturut periode 2014-2018. 2) Bank umum negara dan swasta nasional yang terdaftar di BEI yang memiliki return on asset (ROA) positif selama periode 2014-2018. 3) Laporan keuangan bank umum negara dan swasta nasional yang terdaftar di BEI lengkap berturut-turut periode 2014-2018. Berdasarkan pendekatan purposive sampling di atas maka sampel dalam penelitian di dapatkan 29 Bank periode 2014-2018. Penelitian ini menggunakan metode observasi non participant. metode observasi non participant, yaitu observasi yang dilakukan dengan membaca, mengumpulkan, mencatat data-data tanpa melibatkan diri dan hanya sebagai pengamat independen (Ariwidanta, 2016).

\section{HASIL DAN PEMBAHASAN}

Nilai rata-rata variabel NPL sebesar 2,7077 dengan standar deviasi sebesar 1,50048 atau 15,0048 persen, artinya terjadi penyimpangan NPL terhadap nilai rata-rata NPL sebesar 15,0048 persen. Nilai minimum dan maksimum berarti 
bank memiliki NPL paling rendah sebesar 0,21 dan paling tinggi sebesar 8,54 Nilai rata-rata variabel BOPO sebesar 83,8421 dengan standar deviasi sebesar 10,43449 atau 1043,449 persen, artinya terjadi penyimpangan BOPO terhadap nilai rata-rata BOPO sebesar 1043,449 persen. Nilai minimum dan maksimum berarti bank memiliki BOPO rendah sebesar 52,94 dan paling tinggi sebesar 101,01

Tabel 1.

Hasil Analisis Statistik Deskriptif

\begin{tabular}{lrrrrr}
\hline \multicolumn{1}{c}{ Variabel } & N & Minimum & Maximum & Mean & Std. Deviation \\
\hline Non performing loan & 145 & 0.21 & 8.54 & 2.7077 & 1.50048 \\
Biaya operasional & 145 & 52.94 & 101.01 & 83.8421 & 10.43449 \\
pendapatan operasional & 145 & 41.99 & 145.26 & 82.7422 & 15.93151 \\
Loan to deposit ratio & 145 & 0.82 & 35.12 & 20.0952 & 5.16289 \\
Capital adequacy ratio & 145 & 0.09 & 4.73 & 1.8060 & 1.08105 \\
Return on asset & & & & & \\
\hline
\end{tabular}

Sumber: Data Diolah, 2019

Nilai rata-rata variabel NPL sebesar 82,7422 dengan standar deviasi sebesar 15,93151 atau 1593,151 persen, artinya terjadi penyimpangan LDR terhadap nilai rata-rata LDR sebesar 1593,151 persen. Nilai minimum dan maksimum berarti bank memiliki LDR paling rendah sebesar 41,99 dan paling tinggi sebesar 145,26. Nilai rata-rata variabel CAR sebesar 20,0952 dengan standar deviasi sebesar 5,16289 atau 516,289 persen, artinya terjadi penyimpangan CAR terhadap nilai rata-rata CAR sebesar 516,289 persen. Nilai minimum dan maksimum berarti bank memiliki CAR paling rendah sebesar 0,082 dan paling tinggi sebesar 35,12. Nilai rata-rata variabel ROA sebesar 1,8060 dengan standar deviasi sebesar 1,08105 atau 108,105 persen, artinya terjadi penyimpangan ROA terhadap nilai rata-rata ROA sebesar 15,0048 persen. Nilai minimum dan maksimum berarti bank memiliki ROA paling rendah sebesar 0,09 dan paling tinggi sebesar 4,73

Model analisis regresi linear berganda digunakan untuk mendapat koefisien regresi yang akan menentukan apakah hipotesis yang dibuat akan diterima atau ditolak. Hasil analisis ini mengacu pada hasil pengaruh NPL, BOPPO, LDR, dan CAR terhadap ROA pada perbankan di Indonesia yang terdaftar di BEI periode 2014-2018.

Tabel 2.

Hasil Analisis Regresi Linear Berganda

\begin{tabular}{|c|c|c|c|c|}
\hline \multirow{2}{*}{ Variabel } & \multicolumn{2}{|c|}{ Koefisien Regresi } & \multirow[b]{2}{*}{$\mathbf{t}$} & \multirow{2}{*}{ Sig } \\
\hline & B & Std. error & & \\
\hline Non performing loan & $-0,086$ & 0,042 & $-2,056$ & 0,042 \\
\hline Biaya operasional pendapatan operasional & $-0,064$ & 0,006 & $-10,571$ & 0,000 \\
\hline Loan to deposit ratio & 0,010 & 0,004 & 2,569 & 0,011 \\
\hline Capital adequacy ratio & 0,027 & 0,011 & 2,413 & 0,017 \\
\hline (Constant) & & & & \\
\hline F Statistik & & & & \\
\hline$: \quad 0,000$ & & & & \\
\hline
\end{tabular}

Sumber : Data Diolah, 2019 
Berdasarkan Tabel 2. dapat ditulis persamaan regresi linear berganda sebagai berikut.

$\mathrm{Y}=62,082-0,086 \mathrm{X}_{1}-0,064 \mathrm{X}_{2}+0,010 \mathrm{X}_{3}+0,027 \mathrm{X}_{4}+\mathrm{e}$

$\mathrm{X}_{1}=-0,086$, menunjukkan bahwa "NPL berpengaruh negatif terhadap return on asset pada perbankan di Indonesia yang terdaftar di BEI periode 20142018 dengan kata lain apabila NPL mengalami peningkatan maka ROA pada perbankan di Indonesia yang terdaftar di BEI periode 2014-2018 menurun sebesar 0,086."

$\mathrm{X}_{2}=-0,064$, menunjukkan bahwa "BOPO berpengaruh negatif terhadap ROA pada perbankan di Indonesia yang terdaftar di BEI periode 2014-2018 dengan kata lain apabila BOPO mengalami peningkatan maka ROA pada perbankan di Indonesia yang terdaftar di BEI periode 2014-2018 menurun sebesar 0,064."

$\mathrm{X}_{3}=+0,010$, menunjukkan bahwa "LDR berpengaruh positif terhadap ROA pada perbankan di Indonesia yang terdaftar di BEI periode 2014-2018 dengan kata lain apabila loan to deposit ratio mengalami peningkatan maka ROA pada perbankan di Indonesia yang terdaftar di BEI periode 2014-2018 meningkat sebesar 0,010."

$\mathrm{X}_{4}=+0,027$, menunjukkan bahwa "CAR berpengaruh positif terhadap ROA pada perbankan di Indonesia yang terdaftar di BEI periode 2014-2018 dengan kata lain apabila CAR mengalami peningkatan maka ROA pada perbankan di Indonesia yang terdaftar di BEI periode 2014-2018 meningkat sebesar 0,027."

Tabel 3.

Uji Normalitas

\begin{tabular}{lr}
\hline & $\begin{array}{c}\text { Unstandardized } \\
\text { Residual }\end{array}$ \\
\hline $\mathrm{N}$ & 145 \\
Kolmogorov-Smirnov Z & 0,653 \\
Asymp. Sig. (2-tailed) & 0,128 \\
\hline
\end{tabular}

Sumber : Data Diolah, 2019

Berdasarkan uji normalitas dengan menggunakan One-Sample KolmogorovSmirnov (KS) yang ditampilkan pada Tabel 3. tersebut menunjukkan bahwa besarnya nilai Asymp. Sig. (2-tailed) KS adalah sebesar 0,128. Nilai Asymp. Sig. (2-tailed) KS lebih besar dibandingkan dengan level of significant sebesar 0,05 maka hasil diterima yang mengindikasikan bahwa data yang digunakan pada penelitian ini terdistribusi secara normal, sehingga dapat disimpulkan bahwa model memenuhi syarat.

Berdasarkan Tabel 4. persamaan regresi linier berganda memiliki nilai DW sebesar 2,058. Jumlah sampel 145 dan terdapat 4 variabel bebas, maka nilai du diperoleh sebesar 1,786 dan nilai 4-du sebesar 2,214. Jadi nilai DW berada diantara nilai du dan nilai 4-du, sehingga persamaan regresi linear berganda bebas dari adanya autokorelasi. 
Tabel 4.

Hasil Uji Autokorelasi

\begin{tabular}{lll}
\hline Model & Durbin-Watson & \\
\hline 1 & & $2.058^{\mathrm{a}}$ \\
\hline Sumber $:$ Data Diolah, 2019 &
\end{tabular}

Tabel 5.

Uji Multikolinieritas

\begin{tabular}{|c|c|c|}
\hline \multirow{2}{*}{ Variabel } & \multicolumn{2}{|c|}{ Collinearity Statistics } \\
\hline & Tolerance & VIF \\
\hline Non performing loan & .748 & 1.337 \\
\hline Biaya operasional pendapatan operasional & .730 & 1.370 \\
\hline Loan to deposit ratio & .801 & 1.249 \\
\hline Capital adequacy ratio & .877 & 1.140 \\
\hline
\end{tabular}

Sumber : Data Diolah, 2019

Berdasarkan Tabel 5. tersebut ditunjukkan bahwa tidak terdapat variabel bebas yang memiliki nilai tolerance kurang dari 0,10 dan juga tidak ada variabel bebas yang memiliki nilai VIF lebih dari 10. Maka dari pada itu model regresi bebas dari gejala multikoleniaritas.

Tabel 6.

Uji Heteroskedastisitas

\begin{tabular}{lccccc}
\hline \multicolumn{1}{c}{ Variabel } & \multicolumn{2}{c}{$\begin{array}{c}\text { Unstandardized } \\
\text { Coefficients } \\
\text { B }\end{array}$} & $\begin{array}{c}\text { Standardized } \\
\text { Coefficients } \\
\text { Beta }\end{array}$ & T & Sig. \\
\hline (Constant) & -0.031 & 0.517 & & -0.061 & 0.952 \\
Non Performing Loan & -0.072 & 0.030 & -0.223 & -1.412 & 0.147 \\
Biaya operasional pendapatan & 0.002 & 0.004 & 0.033 & 0.352 & 0.725 \\
operasional & 0.004 & 0.003 & 0.127 & 1.419 & 0.158 \\
Loan to deposit ratio & 0.010 & 0.008 & 0.106 & 1.246 & 0.215 \\
Capital adequacy ratio & & & & &
\end{tabular}

Sumber : Data Diolah, 2019

Masing - masing model memiliki nilai signifikansi lebih besar dari 5 persen atau 0,05. Hal ini menunjukkan bahwa variabel bebas yang digunakan pada penelitian ini tidak berpengaruh secara signifikan terhadap variabel terikatnya yaitu absolute error, maka dari itu, penelitian ini bebas dari gejala heteroskedastisitas.

Tabel 7.

Uji Derterminasi

\begin{tabular}{lcccc}
\hline Model & R & R Square & Adjusted R Square & $\begin{array}{c}\text { Std. Error of the } \\
\text { Estimate }\end{array}$ \\
\hline 1 & $0.804^{\mathrm{a}}$ & 0.647 & 0.637 & .65141 \\
\hline Sumber : Data Diolah, 2019 & & & &
\end{tabular}


Berdasarkan hasil tersebut diketahui bahwa nilai adjr ${ }^{2}=63,7$ persen yang berarti bahwa sebesar 63,7 persen ROA pada perbankan di Indonesia yang terdaftar di BEI periode 2014-2018 dipengaruhi oleh NPL, BOPO, LDR, dan CAR lalu sisanya sebesar 36,3 persen dipengaruhi oleh variabel lain yang tidak diteliti pada penelitian ini.

Tabel 8.

Hasil Uji F

\begin{tabular}{rlrrrrr}
\hline & Model & Sum of Squares & Df & Mean Square & F & Sig. \\
\hline & Regression & 108.882 & 4 & 27.220 & 64.149 & $0.000^{\mathrm{b}}$ \\
1 & Residual & 59.406 & 140 & 0.424 & & \\
& Total & 168.288 & 144 & & & \\
\hline
\end{tabular}

Sumber : Data Diolah, 2019

Uji F dengan variabel NPL $\left(\mathrm{X}_{1}\right)$, variabel BOPO $\left(\mathrm{X}_{2}\right)$, LDR $\left(\mathrm{X}_{3}\right)$, dan CAR $\left(\mathrm{X}_{4}\right)$ terhadap ROA (Y) secara serempak (uji F) dengan menggunakan program Statistical Package for Social Science (SPSS) version 22,0 for windows, pada tabel ANOVA diketahui $F_{\text {sig }}$ sebesar 0,000. Nilai signifikansi $F$ adalah $0,000<$ 0,05 , berarti bahwa variabel NPL $\left(\mathrm{X}_{1}\right)$, variabel BOPO $\left(\mathrm{X}_{2}\right), \operatorname{LDR}\left(\mathrm{X}_{3}\right)$, dan CAR $\left(\mathrm{X}_{4}\right)$ secara simultan berpengaruh secara signifikan terhadap ROA (Y) pada perbankan di Indonesia yang terdaftar di BEI periode 2014-2018, atau model yang digunakan dalam penelitian layak dan dapat dipergunakan untuk analisis berikutnya.

Tabel 9.

Hasil Uji t

\begin{tabular}{lcrc}
\hline \multicolumn{1}{c}{ Variabel } & $\begin{array}{c}\text { Unstandardized Coefficients } \\
\text { Beta }\end{array}$ & t hitung & Sig. \\
\hline Non performing loan & $-0,086$ & $-2,056$ & 0,042 \\
$\begin{array}{l}\text { Biaya operasional pendapatan } \\
\text { operasional }\end{array}$ & $-0,064$ & $-10,571$ & 0,000 \\
Loan to deposit ratio & & & \\
Capital adequacy ratio & 0,010 & 2,569 & 0,011 \\
\hline
\end{tabular}

Sumber : Data Diolah, 2019

Hasil uji t menunjukkan sig NPL $\left(\mathrm{X}_{1}\right)$ sebesar 0,042 lebih kecil dari nilai signifikansi 0,05 berarti bahwa NPL berpengaruh negatif signifikan terhadap ROA pada perbankan di Indonesia yang terdaftar di BEI periode 2014-2018. Koefisien regresi $\left(\mathrm{X}_{1}\right)$ sebesar $-0,086$, menunjukkan bahwa meningkatnya NPL maka akan menurunkan ROA (Y) pada perbankan di Indonesia yang terdaftar di 
BEI periode 2014-2018. Sehingga hipotesis pertama dalam penelitian ini diterima.

Hasil uji t menunjukkan sig BOPO $\left(\mathrm{X}_{2}\right)$ sebesar 0,000 lebih kecil dari nilai signifikansi 0,05 , berarti bahwa variabel BOPO $\left(\mathrm{X}_{2}\right)$ berpengaruh negatif signifikan terhadap ROA (Y) pada perbankan di Indonesia yang terdaftar di BEI periode 2014-2018 Koefisien regresi $\left(\mathrm{X}_{2}\right)$ sebesar -0,064, menunjukkan bahwa meningkatnya biaya operasional pendapatan operasional maka akan meningkatkan ROA pada perbankan di Indonesia yang terdaftar di BEI periode 2014-2018. Sehingga hipotesis kedua dalam penelitian ini diterima.

Hasil uji t menunjukkan sig LDR $\left(\mathrm{X}_{3}\right)$ sebesar 0,011 lebih kecil dari nilai signifikansi 0,05 , berarti bahwa variabel LDR berpengaruh positif signifikan terhadap ROA pada perbankan di Indonesia yang terdaftar di BEI periode 20142018. Koefisien regresi $\left(\mathrm{X}_{3}\right)$ sebesar 0,010 , menunjukkan bahwa meningkatnya LDR maka akan meningkatkan ROA pada perbankan di Indonesia yang terdaftar di BEI periode 2014-2018. Sehingga hipotesis tiga dalam penelitian ini dierima.

Hasil uji t menunjukkan sig CAR $\left(\mathrm{X}_{4}\right)$ sebesar 0,017 lebih kecil dari nilai signifikansi 0,05 , berarti bahwa variabel CAR $\left(\mathrm{X}_{4}\right)$ berpengaruh positif signifikan terhadap ROA (Y) pada perbankan di Indonesia yang terdaftar di BEI Periode 2014-2018. Koefisien regresi $\mathrm{X}_{4}$ sebesar 0,027, menunjukkan bahwa meningkatnya CAR maka akan meningkatkan ROA pada perbankan di Indonesia yang terdaftar di BEI periode 2014-2018. Sehingga hipotesis keempat dalam penelitian ini dierima.

Berdasarkan pengolahan data SPSS dihasilkan tingkat signifikansi berdasarkam hasil uji t sebesar 0,042 lebih kecil dari level of significant sebesar 0,05 dengan koefisien beta sebesar $-0,086$. Berdasarkan nilai pengujian tersebut dapat dilihat koefisien beta variabel $\left(\mathrm{X}_{1}\right)$ adalah $-0,086$ artinya NPL berpengaruh negatif terhadap ROA pada perbankan di Indonesia yang terdaftar di BEI periode 2014-2018 dengan tingkat signifikansi 0,042 lebih kecil dari level of significant sebesar 0,05 menunjukan pengaruh yang signifikan antara NPL terhadap ROA sehingga hipotesis pertama "NPL berpengaruh negatif terhadap ROA pada bank umum negara dan swasta nasional di BEI periode 2014-2018" diterima.

Hasil penelitian ini menunjukan bahwa nilai negatif pada koefisien beta mengartikan bank umum negara dan swasta nasional pada BEI dalam menangani kredit bermasalah dapat dikelola dengan efektif dan efisien. Menurut Buchory (2015) pengelolaan kredit yang gagal akan menyebabkan kemampuan bank untuk memberikan pinjaman baru terbatas, maka dari itu keuntungan yang didapatkan akan menurun. Tingginya kredit gagal atau macet membuat bank mengalami kerugian karena kualitas kredit yang diberikan buruk membuat jumlah kredit macet meningkat dan otomatis NPL tinggi (Silaban, 2017). NPL yang tinggi menyebabkan bank membentuk cadangan kerugian yang membuat pendapatan bunga pinjaman akan berkurang sehingga retun on asset pada bank akan menurun.

Hasil penelitian ini sesuai dengan penelitian yang dilakukan oleh penelitian Puspitasari et al. (2015), Petria et al. (2015), Prasetyo \& Darmayanti (2015), Bhattarai (2016), Chimkono et al. (2016), Warsa \& Mustanda (2016), Ariwidanta (2016), Silaban (2017), Yudha et al. (2017), Kadioglu et al. (2017), Hakim \& Sugianto (2018), Peling \& Sedana (2018), Putri dkk. (2018), Afriyeni \& Fernos 
(2018), serta Paramita \& Dana (2019) menyatakan bahwa NPL berpengaruh negatif terhadap ROA.

Berdasarkan pengolahan data SPSS dihasilkan tingkat signifikansi 0,000 lebih kecil dari level of significant sebesar 0,05 dengan koefisien beta sebesar 0,064 . Berdasarkan nilai pengujian tersebut, dapat dilihat koefisien beta variabel $\left(\mathrm{X}_{2}\right)$ adalah $-0,064$ artinya BOPO berpengaruh negatif terhadap ROA pada perbankan di Indonesia yang terdaftar di BEI periode 2014-2018 dengan tingkat signifikansi 0,000 lebih kecil dari level of significant sebesar 0,05 menunjukan pengaruh yang signifikan antara BOPO terhadap ROA sehingga hipotesis kedua "BOPO berpengaruh negatif terhadap ROA pada bank umum negara dan swasta nasional di BEI periode 2014-2018" diterima.

Hasil penelitian ini menunjukan bahwa nilai negatif pada koefisien beta mengartikan bank umum negara dan swasta nasional pada BEI dapat menekan biaya operasional dan meningkatkan pendapatan opersional secara baik. Menurut Kusmayadi (2018) BOPO digunakan untuk menilai kemampuan manajemen bank dalam mengendalikan operasional bank. Semakin kecil rasio BOPO menunjukkan bank tidak pada kondisi bermasalah karena dapat mengelola biaya operasional dan pendapatan operasional secara efektif dan efsien. Tingginya BOPO menggambarkan bahwa bank belum mampu mengelola sumber yang ada secara efektif dan efisien dalam menekan biaya operasional sehingga dapat berakibat pada penurunan ROA (Vernanda \& Widyarti, 2016).

Hasil penelitian ini sesuai dengan penelitian yang dilakukan oleh Buchory (2015), Utami (2015), Buchory (2015), Prasetyo \& Darmayanti (2015), Vernanda \& Widyarti (2016), Yusuf \& Surjaatmadja (2018), Juwita et al. (2018), Kusmayadi (2018), Peling \& Sedana (2018), Purnomo dkk. (2018), Putri dkk. (2018), Afriyeni \& Fernos (2018) serta Yuniari \& Badjra (2019) menyatakan bahwa BOPO berpengaruh negatif terhadap ROA.

Berdasarkan pengolahan data SPSS dihasilkan tingkat signifikansi 0,011 lebih kecil dari level of significant sebesar 0,05 dengan koefesien beta sebesar 0,010 . Berdasarkan nilai pengujian tersebut dapat dilihat koefisien beta variabel $\left(\mathrm{X}_{3}\right)$ adalah $+0,010$ artinya LDR berpengaruh positif terhadap ROA pada perbankan di Indonesia yang terdaftar di BEI periode 2014-2018 dengan tingkat signifikansi 0,000 lebih kecil dari level of significant sebesar 0,05 menunjukan pengaruh yang signifikan antara LDR terhadap ROA sehingga hipotesis ketiga "LDR berpengaruh positif terhadap ROA pada bank umum negara dan swasta nasional di BEI periode 2014-2018” diterima.

Hasil penelitian ini menunjukan bahwa nilai positif pada koefisien beta mengartikan bank umum negara dan swasta nasional pada BEI dapat mengelola likuditas bank secara efektif dan efisien. Menurut Utami (2015) LDR yang baik ketika tidak ada uang menganggur yang tidak akan menyebabkan naiknya biaya peluang akibat uang menganggur karena tidak ada penyauran kredit dengan baik. Tingginya LDR dapat meningkatka ROA pada suatu bank (Yudha et al., 2017). LDR tinggi dapat memperlihatkan penyaluran kredit yang dilakukan pihak bank pada dana pihak ketiga (DPK) lancar yang berakibat pada peningkatan ROA begitu sebaliknya ketika LDR rendah penyaluran kredit pada DPK tidak lancar 
dan menyebabkan biaya yang meningkat akibat tidak lancarnya penyaluran kredit yang menyebabkan penurunan ROA pada bank.

Hasil penelitian ini sesuai dengan penelitian yang dilakukan oleh Utami (2015), Prasetyo \& Darmayanti (2015), Chou \& Buchdadi (2016), Yudha et al. (2017), Juwita et al. (2018), Peling \& Sedana (2018), Afriyeni \& Fernos (2018), Paramita \& Dana (2019) serta Yuniari \& Badjra (2019) menyatakan bahwa LDR berpengaruh positif terhadap ROA.

Berdasarkan pengolahan data SPSS dihasilkan tingkat signifikansi 0,017 lebih kecil dari level of significant sebesar 0,05 dengan koefisien beta sebesar 0,027. Berdasarkan nilai pengujian tersebut dapat dilihat dengan koefisien beta variabel $\left(\mathrm{X}_{4}\right)$ adalah $+0,027$ CAR berpengaruh positif terhadap ROA pada perbankan di Indonesia yang terdaftar di BEI periode 2014-2018 dengan tingkat signifikansi 0,017 lebih kecil dari level of significant sebesar 0,05 menunjukan pengaruh yang signifikan antara CAR terhadap ROA sehingga hipotesis keempat "CAR berpengaruh positif terhadap ROA pada bank umum negara dan swasta nasional di BEI periode 2014-2018" diterima.

Hasil penelitian ini menunjukan bahwa nilai positif pada koefisien beta mengartikan bank umum negara dan swasta nasional pada BEI dapat menyediakan modal minimum dan mengelola modal bank secara efektif dan efisien. Menurut Yusuf \& Surjaatmadja (2018) penyediaan modal yang tinggi dapat meningkatkan peluang untuk meningkatkan ROA pada bank. Kegagalan dalam mengukur modal pada bank dapat menimbulkan kerugian dari kurangnya pemenuhan modal minimum bank melalui rasio CAR. CAR yang memadai dapat menutupi kerugian bank yang berakibat pada peningkatan ROA (Iftikhar, 2016). Semakin tinggi CAR maka semakin baik bank dalam mengatasi risiko kerugian yang dapat menurunkan ROA pada bank (Purnomo dkk, 2018).

Hasil penelitian ini sesuai dengan penelitian yang dilakukan oleh Utami (2015), Iftikhar (2016), Vernanda \& Widyarti (2016), Juwita et al. (2018), Yusuf \& Surjaatmadja (2018), Akbar dkk. (2018), Putri dkk. (2018), Afriyeni \& Fernos (2018), Atmoko dkk. (2018) serta Paramita \& Dana (2019) menyatakan bahwa CAR berpengaruh positif terhadap ROA

Berdasarkan hasil penelitian ini, dari keempat variabel bebas yang diteliti, variabel NPL dan variabel BOPO mempunyai pengaruh negatif signifikan terhadap ROA. Hal ini memperlihatkan bahwa NPL yang rendah dapat meningkatkan ROA pada bank. NPL yang rendah juga dapat mencegah pembentukan PPAP atau cadangan kerugian yang dapat menurunkan profitabilitas (ROA) yang merugikan bank. Hasil ini selaras dengan hasil penelitian Puspitasari et al. (2015), Petria et al. (2015), Prasetyo \& Darmayanti (2015), Bhattarai (2016), Chimkono et al. (2016), Warsa \& Mustanda (2016), Ariwidanta (2016), Silaban (2017), Yudha et al., (2017), Kadioglu et al. (2017), Hakim \& Sugianto (2018), Peling \& Sedana (2018), Putri dkk. (2018), Afriyeni \& Fernos (2018), serta Paramita \& Dana (2019).

Variabel BOPO juga menunjukkan pengaruh negatif signifikan terhadap return on asset. Hal ini memperlihatkan biaya operasional rendah meningkatkan pendapatan operasional yang dapat mempengaruhi peningkatan profitabilitas (return on asset) bank. Hasil penelitian ini selaras dengan penelitian Buchory 
(2015), Utami (2015), Buchory (2015), Prasetyo \& Darmayanti (2015), Vernanda \& Widyarti (2016), Yusuf \& Surjaatmadja (2018), Juwita et al. (2018), Kusmayadi (2018), Peling \& Sedana (2018), Purnomo dkk. (2018), Putri dkk. (2018), Afriyeni \& Fernos (2018) serta Yuniari \& Badjra (2019).

Dua variabel bebas lainnya yaitu variabel LDR dan variabel CAR menujukkan pengaruh positif signifikan terhadap ROA. Hal ini meperlihatkan LDR yang tinggi dapat meningkatkan profitabilitas (ROA) pada bank. Hasil penelitian ini selaras dengan penelitian Utami (2015), Prasetyo \& Darmayanti (2015), Chou \& Buchdadi (2016), Yudha et al. (2017), Juwita et al. (2018), Peling \& Sedana (2018), Afriyeni \& Fernos (2018), Paramita \& Dana (2019) serta Yuniari \& Badjra (2019).

Variabel selanjutnya yaitu CAR menunjukkan pengaruh positif signifikan terhadap ROA. Hal ini memperlihatkan CAR yang tinggi mampu meningkatkan profitabilitas (ROA) pada bank. Pemenuhan modal yang cukup (minimum) dapat membantu pihak bank dalam menangani risiko yang mungkin terjadi untuk menurunkan profitabilitas bank tersebut. Hasil penelitian ini selaras dengan penelitian Utami (2015), Iftikhar (2016), Vernanda \& Widyarti (2016), Juwita et al. (2018), Yusuf \& Surjaatmadja (2018), Akbar dkk. (2018), Putri dkk. (2018), Afriyeni \& Fernos (2018), Atmoko dkk. (2018) serta Paramita \& Dana (2019).

Berdasarkan hasil penelitian ini, menujukkan informasi bahwa variabel yang diteliti yaitu variabel NPL dan BOPO memiliki pengaruh negatif signifikan terhadap ROA, sedangkan variabel LDR dan CAR memiliki pengaruh positif signifikan terhadap ROA. Hasil penelitian ini memberikan informasi pada pihak bank umum negara dan swasta nasional di BEI dan masyarakat yang ingin menghimpun dana di bank tersebut untuk memperhatikan tingkat kinerja bank yang dipengaruhi oleh keempat variabel penelitian ini untuk dikendalikan, khususnya NPL dan BOPO demi mempertahankan serta meningkatkan profitabilitas yang dinilai dengan variabel ROA Pihak bank dapat menggunakan strategi kehati-hatian dalam penyaluran kredit serta memperhatikan biaya operasional yang dikeluarkan dengan menggunakan strategi laba tetap atau meningkatkan pendapatan operasional dengan biaya operasional tetap.

Penelitian ini diharapkan juga mampu memberikan informasi serta pertimbangan untuk pihak masyarakat dalam memberikan dana ke bank atau ingin meminjam dana pada bank tersebut. Variabel penelitian NPL, BOPO, LDR, dan CAR merupakan beberapa faktor yang dapat mempengaruhi pendapatan profitabilitas bank (ROA) serta kinerja bank tersebut Profitabilitas bank yang meningkat menggambarkan suatu kinerja bank dapat dikatakan baik dalam mengelola bank dan dapat mengelola dengan baik faktor risiko yang dapat menurunkan profitabilitas bank tersebut. Profitabilitas yang menurun atau negatif dapat menunjukkan suatu bank tidak dapat mengelola dengan baik faktor risiko yang mengurangi profitabilitas bank tersebut.

\section{SIMPULAN}

NPL berpengaruh negatif signifikan terhadap ROA pada perbankan di Indonesia yang terdaftar di BEI periode 2014-2018. BOPO berpengaruh negatif 
signifikan terhadap ROA pada perbankan di Indonesia yang terdaftar di BEI periode 2014-2018. LDR berpengaruh positif signifikan terhadap ROA ada perbankan di Indonesia yang terdaftar di BEI priode 2014-2018. CAR berpengaruh positif signifikan terhadap ROA pada perbankan di Indonesia yang terdaftar di BEI periode 2014-2018.

Bagi pihak bank disarankan menerapkan strategi kehati-hatian dalam penyaluran kredit dengan menganalisis kredit yang disalurkan, salah satunya dapat menggunakan prinsip $5 \mathrm{C}$ perbankan dalam mengatasi hal penyaluran kredit yaitu character (kepribadian nasabah), capacity (kemampuan nasabah), capital (aset atau kekayaan yang dimiliki nasabah), collateral (jaminan nasabah), dan condition (faktor luar dari pihak bank maupun nasabah) dan bank disarankan dapat lebih memperluas serta memperbanyak penyaluran kredit yang menguntungkan bank dalam meningkatkan profitabilitas bank.

Bank diharapkan mengendalikan serta mengurangi biaya operasional yang dapat merugikan dan menurunkan profitabilitas dengan meningkatkan pendapatan operasional dari bank. Bank dapat menerapkan strategi laba tetap yaitu denga mengendalikan atau memotong biaya-biaya berisiko yang masih bisa diminimalisir untuk meningkatkan pendapat operasional bank.

Bank diharapkan memperhatikan tingkat likuditasnya khususnya menggunakan rasio LDR. LDR yang stabil serta tinggi diharapkan mampu menjaga dan meningkatkan profitabilitas bank. Bank juga dapat menggunakan strategi dengan mengandalkan dana pihak kedua seperti pinjaman bank lain (Bank Indonesia) saat LDR terlalu tinggi untuk memberikan dana dalam mengatasi risiko likuiditas yang dapat menurunkan profitabilitas bank tersebut.

Bank diharapkan dapat memenuhi kewajiban modal minimumnya melalui CAR untuk mengatasi risiko modal. Bank dapat menerapkan atau mencadangkan modalnya untuk mengatasi risiko yang terjadi di masa depan yang dapat menurunkan profitabilitas bank atau dengan memperhatikan risiko aset pada bank yang bisa merugikan bank tersebut. CAR yang terpenuhi dan tinggi mampu menjaga bank dari risiko yang merugikan bank serta mampu meningkatkan profitabilitas bank.

Penelitian selanjutnya diharapkan dapat memperluas lingkup penelitian, bukan hanya di pada perbankan di Indonesia yang terdaftar di BEI periode 20142018 yang relatif hanya 5 tahun tetapi mungkin bisa lebih luas dan periode yang lebih lama. Disarankan kepada peneliti selanjutnya dapat menggunakan variable yang lebih banyak dan luas yang dapat mempengaruhi ROA pada perbankan Indonesia di BEI.

\section{REFERENSI}

Afriyeni, \& Fernos, J. (2018). Analisis Faktor-Faktor Penentu Kinerja Profitabilitas Bank Perkresitan Rakyat (BPR) Konvensional di Sumatera Barat. Jurnal Benefita, 3(3), 325-335.

Akbar, M. T., P., M., \& Djazuli, A. (2018). Pengaruh Kredit Macet Terhadap Profitabilitas Melalui Kecukupan Modal, Biaya dan Pendapatan Operasional 
(Studi Pada Bank Umum Swasta Nasional yang Terdaftar di BEI). Jurnal Bisnis Dan Manajemen, 5(1), 79-91.

Anwar, Y., \& Murwaningsari, E. (2017). The effect of Credit Risk and Capital Adequacy Ratio Upon Return on Asset (A Case Study at Banking Listed in Indonesia Stock Exchange). The Accounting Journal of BIANIAGA, 2(2), 2338 .

Ariwidanta, K. T. (2016). Pengaruh Risiko Kredit Terhadap Profitabilitas dengan Kecukupan Modal Sebagai Variabel Mediasi. E-Jurnal Manajemen Unud, 5(4), 2311-2340.

Atmoko, A. S., Amboningtyas, D., \& Fathoni, A. (2018). Effect of LDR, NPL and BOPO on Profitabilities Based on CAR (Case Study on Banking Companies Listed on the Indonesia Stock Exchange Period 2013-2017). Journal of Management, 4(4), 1-17.

Bhattarai, Y. R. (2016). Effect of Credit Risk on The Performance of Nepalese Commercial Banks. Prestige E-Journal of Management and Research, 3(1), $51-70$.

Buchory, H. A. (2015). Banking Intermediation, Operational Efficiency and Credit Risk in The Banking Profitability. International Journal of Business, Economics and Law, 7(2), 57-63.

Chimkono, E. E., Muturi, W., \& Njeru, A. (2016). Effect of Non Performing Loans and Other Factors on Performance of Commercial Banks in Malawi. International Journal Od Economics, Commerce and Management, 4(2), 549-563.

Chou, T., \& Buchdadi, A. D. (2016). Bank Performance and Its Underlying Factors: A Study of Rural Banks in Indonesia. Accounting and Finance Research, 5(3), 55-63. https://doi.org/10.5430/afr.v5n3p55

Febriyono, T. J. (2015). Faktor-Faktor Yang Mempengaruhi Profitabilitas Bank Perkreditan Rakyat (BPR) di Provinsi Jawa Timur. Jurnal Akuntansi Dan Keuangan Unja, 2(1), 63-76.

Hakim, L., \& Sugianto. (2018). Determinant Profitability and Implications on The Value of The Company: Empirical Study on Banking Industry in IDX. International Journal of Economics and Financial, 8(1), 205-216.

Iftikhar, M. (2016). Impact of Credit Risk Management on Financial Performance of Commercial Banks of Pakistan. University of Haripur Journal of Management (UOHJM), 1(2), 110-125. 
Juwita, S., Raga, P. D. J., Prasetyo, F. I., \& Rimawan, E. (2018). Effect of CAR (Capital Adequacy Ratio), BOPO (Operational Costs on Operational Revenues) and LDR (Loan to Deposit Ratio) to ROA (Return on Assets) PD Bank Pasar Bogor City. International Journal of Innovative Science and Research Technology, 3(6), 305-309.

Kadioglu, E., Telceken, N., \& Ocal, N. (2017). Effect of The Asset Quality on The Bank Profitability. International Journal of Economics and Finance, 9(7), 60-68. https://doi.org/10.5539/ijef.v9n7p60

Kasmir. (2016). Bank dan Lembaga Keuangan Lainnya (Edisi Revisi 2014) (Revisi2014 ed.). Jakarta: Rajawali Pers.

Kasmir. (2017). Manajemen Keuangan Perbankan (Edisi Revisi) (Revisi). Jakarta: Rajawali Pers.

Kusmayadi, D. (2018). Analysis of Effect of Capital Adequacy Ratio , Loan to Deposit Ratio, Non Performing Loan , BOPO, and Size on Return on Assets in Rural Banks at Indonesia. Saudi Journal of Business and Management Studies (SJBMS), 3(7), 786-795. https://doi.org/10.21276/sjbms.2018.3.7.4

Munawar, A. H. (2017). Pengaruh Capital Adequacy Ratio Terhadap Return on Asset (Kasus PT Bank Mandiri Tbk). Jurnal Ilmiah Adbis, 2(1), 1-8.

Paramita, P. K., \& Dana, I. M. (2019). Pengaruh Capital Adequacy Ratio, Non Performing Loan, dan Loan to Deposit Ratio Terhadap Profitabilitas. EJurnal Manajemen Unud, 8(2), 7633-7659. https://doi.org/https://doi.org/10.24843/EJMUNUD.2019.v8.i2.p4

Peling, I. A. A., \& Sedana, I. B. P. (2018). Pengaruh LDR, NPL, dan BOPO Terhadap Profitabilitas Pada PT. BPD Bali Periode Tahun 2009-2016. EJurnal Manajemen Unud, 7(6), 2999-3026. https://doi.org/https://doi.org/10.24843/EJMUNUD.2018.v7.i06.p6 ISSN

Petria, N., Capraru, B., \& Ihnatov, I. (2015). Determinants of Banks Profitability : Evidence From EU 27 Banking Systems. Procedia Economics and Finance, 20(15), 518-524. https://doi.org/10.1016/S2212-5671(15)00104-5

Prasetyo, D. A., \& Darmayanti, N. P. A. (2018). Pengaruh Risiko Kredit, Likuiditas, Kecukupan Modal, dan Efisiensi Operasional Terhadap Profitabilitas pada PT BPD Bali. E-Jurnal Manajemen Unud, 4(9), 25902617.

Purnomo, E., Sriwidodo, U., \& Wibowo, E. (2018). Pengaruh Rasio Keuangan Terhadap Kinerja Keuangan Pada Bank Umum Swasta Nasional Devisa yang Terdaftar di Bursa Efek Indonesia Periode 2013-2016. Jurnal Ekonomi Dan 
Kewirausahaan, 18(4), 189-198.

Puspitasari, D. M., Setiadi, N. J., \& Rizkiyanti, N. (2015). Implementation of The Indonesian Banking Architecture as A Blueprint of The Direction and Order od The National Banking System: Empirical Study of Indonesian Commercial Banking. Journal The Winners, 16(1), 6-14.

Putri, N. K. A. P., Wiagustini, L. P., \& Abundanti, N. N. (2018). Pengaruh NPL, CAR dan BOPO Terhadap Profitabilitas Pada BPR di Kota Denpasar. EJurnal Manajemen Unud, 7(11), 6212-6238. https://doi.org/https://doi.org/10.24843/EJMUNUD.2018.v7.i11.p15

Putri, R. N. O. S., \& Dewi, S. K. S. (2017). Pengaruh LDR, CAR, NPL, BOPO Terhadap Profitabilitas Lembaga Perkreditan Desa di Kota Denpasar. EJurnal Manajemen Unud, 6(10), 5607-5635.

Riyadi, S. (2006). Banking Assets and Liability Management. Jakarta: FEUI.

Silaban, P. (2017). The Effect of Capital Adequacy Ratio, Net Interest Margin and Non Performing Loans on Bank Profitability: The Case of Indonesia. International Journal of Economics and Business Administration, 5(3), 5869.

Utami, S. R. (2015). Comparison Between Bank Performance of Commercial Bank, State Owned Bank, and Foreign Owned Bank in Indonesia During The Period 2005-2009. International Journal of Advanced Research in Management and Social Sciences, 4(10), 37-54.

Vernanda, S. D., \& Widyarti, E. T. (2016). Analisis Pengaruh CAR, LDR, NPL, BOPO, dan SIZE Terhadap ROA (Studi pada Bank Umum Konvensional yang Terdaftar di Bursa Efek Indonesia Periode 2010-2015). Diponegoro Journal of Management, 5(3), 1-13.

Warsa, N. M. I. U. P., \& Mustanda, I. K. (2016). Pengaruh CAR, LDR dan NPL Terhadap ROA Pada Sektor Perbankan di Bursa Efek Indonesia. E-Jurnal Manajemen Unud, 5(5), 2842-2870.

Wiagustini, L. P. (2014). Manajemen Keuangan. Denpasar: Udayana University Press.

Yudha, A., Chabachib, M., \& Pangestuti, I. R. D. (2017). Analysis of The Effect of NPL, NIM, Non Interest Income, and LDR Toward ROA with Size as Control Variables (Differences Study on Domestic and Foreign Banks Listed on BEI Period 2010-2015). Jurnal Bisnis Strategi, 26(2), 100-113.

Yuniari, N. P., \& Badjra, I. B. (2019). Pengaruh Likuiditas, Efisiensi, dan Ukuran 
Kade Devi Anggreningsih, Pengaruh NPL, Biaya Operasional...

Bank Terhadap Profitabilitas. E-Jurnal Manajemen Unud, 8(6), 3502-3530. https://doi.org/https://doi.org/10.24843/EJMUNUD.2019.v08.i06.p08 ISSN

Yusuf, M., \& Surjaatmadja, S. (2018). Analysis of Financial Performance on Profitability with Non Performance Financing as Variable Moderation (Study at Sharia Commercial Bank in Indonesia Period 2012 - 2016). Journal of Economics and Financial, 8(4), 126-132. 